Vol. 1 No. 4 Oktober 2021 e-ISSN : 2774-6283 | p-ISSN : 2775-0019

\title{
IMPLEMENTASI LAYANAN BIMBINGAN DAN KONSELING TERHADAP PROBLEM BELAJAR SISWA KELAS XI ADMINISTRASI PERKANTORAN 1 TAHUN PELAJARAN 2017/2018
}

\author{
YENI NURYANI \\ SMKN 1 Tanah Grogot \\ e-mail: yeninuryani224@gmail.com
}

\begin{abstract}
ABSTRAK
Tujuan dari penelitian ini adalah: (a) Untuk mengungkap pengaruh Pembelajaran dengan Layanan Bimbingan Dan Konseling terhadap hasil belajar Bimbingan Konseling . (b) Ingin mengetahui seberapa jauh pemahaman dan penguasaan mata pelajaran Bimbingan Konseling setelah diterapkannya Pembelajaran dengan Layanan Bimbingan Dan Konseling. Penelitian ini menggunakan penelitian tindakan (action research) sebanyak tiga putaran. Setiap putaran terdiri dari empat tahap yaitu: rancangan, kegiatan dan pengamatan, refleksi, dan refisi. Sasaran penelitian ini adalah siswa Kelas XI Administrasi Perkantoran 1 Data yang diperoleh berupa hasil tes formatif, lembar observasi kegiatan belajar mengajar. Dari hasil analis didapatkan bahwa prestasi belajar siswa mengalami peningkatan dari siklus I sampai siklus III yaitu, siklus I (72\%), siklus II (88\%). Simpulan dari penelitian ini adalah metode pembelajaran Layanan Bimbingan Dan Konseling dapat berpengaruh positif terhadap motivasi belajar Siswa Kelas XI, serta model pembelajaran ini dapat digunakan sebagai salah satu alternative Bimbingan Konseling.
\end{abstract}

Kata Kunci: Penelitian Tindakan Kelas, Bimbingan Konseling.

\section{ABSTRACT}

The aims of this study are: (a) To reveal the effect of Guidance and Counseling Learning with Guidance and Counseling learning outcomes. (b) Want to know how far the understanding and mastery of Guidance and Counseling subjects is after the implementation of Learning with Guidance and Counseling Services. This study uses three rounds of action research. Each round consists of four stages, namely: design, activities and observations, reflection, and revision. The targets of this study were students of Class XI Office Administration 1. The data obtained were in the form of formative test results, observation sheets for teaching and learning activities. From the results of the analysis, it was found that student learning achievement has increased from cycle I to cycle III, namely, cycle I (72\%), cycle II (88\%). The conclusion of this study is that the Guidance and Counseling Service learning method can have a positive effect on the learning motivation of Class XI students, and this learning model can be used as an alternative to Counseling Guidance.

Keywords: Classroom Action Research, Counseling Guidance.

\section{PENDAHULUAN}

Istilah layanan BK terdiri dari dua kata yakni "bimbingan" dan "konseling”. Bimbingan merupakan pemberian bantuan oleh seseorang kepada orang lain dalam menentukan pilihan, penyesuaian dan pemecahan permasalahan. Bimbingan bertujuan membantu seseorang agar bertambah kemampuan bertangung jawab atas dirinya (Sukardi, 1985).

Perkembangan keilmuan konseling memiliki sejarah yang panjang, di Mesopotamia (Irak), Persia (Iran), dan Mesir, para tokoh agama seperti pendeta kuno melakukan konseling dengan menggunakan mantra-mantra kuno sebagai penyembuh. Menurut Gibson (dalam Lasan, 2015) sejarah perkembangan konseling pada manusia terjadi ketika nabi Adam mendapat konsekuensi akibat makan buah terlarang di Taman Firdaus.

Menurut Habsy (2017) konseling sudah ada sejak Ki Lurah Semar memberikan Konseling pada arjuna yang sedang mengalami konflik batin. Bentuk konselor primitif pada masa lalu diparktikkan oleh kepala suku, tabib, dukun, peramal yang dianggap mampu untuk 
menenangkan hati, atau memberikan prediksi pada masa depan. Meskipun memiliki sejarah panjang namun konsep konseling tetap sulit untuk dijelaskan dikarenakan kurangnya kejelasan publik karena banyak praktisi modern menggunakanlabel konselor.

Menurut Hallen (2002) konseling adalah hubungan tatap muka yang bersifat rahasia, penuh dengan sikap penerimaan dan pemberian kesempatan dari konselor kepada klien, konselor mempergunakan pengetahuan dan keterampilannya untuk membantu kliennya mengatasi masalah-masalahnya. Yang dimaksud dengan layanan bimbingan dan konseling di sini adalah salah satu bentuk sarana dalam BK yang bertujuan untuk mengembangkan keterampilan warga masyarakat. Layanan bimbingan dan konseling mencakup tujuan, kegiatan atau pokok-pokok layanan, pelaksanaan dan hal-hal khusus yang perlu mendapat perhatian yang berkenaan dengan layanan atau kegiatan tersebut.

Secara umum teori konseling merupakan upaya untuk menjelaskan proses serangkaian kegiatan awal, mengembangkan dan mengakhiri kegiatan konseling. Empat tema yang dominan dalam teori konseling adalah kognitif, psikodinamik, humanistik, dan transpersonal. Ada penambahan satu tema dalam teori kepribadian, yakni pendekatan sistemik, namun dalam teori cybernetic (Corey, 2005). Teori konseling memiliki beberapa fungsi yakni sebagai pedoman untuk melayani dan menjelaskan bagaimana manusia belajar, berubah dan mengembangkan, berguna menjadi sebuah model untuk menormalkan fungsi manusia, serta apa yang harus terjadi dalam proses dan hasil konseling. Konselor menggunakan teori untuk mengatur informasi dan pengamatan, untuk menjelaskan konsep masalah konseli, dan menerapkan intervensi khusus dengan konseli (Gysbers, 2001).

Layanan bimbingan dan konseling disini bukan menunjukkan salah satu aspek layanan, melainkan kesemua layanan BK merupakan kesatuan yang utuh yang harus dilaksanakan. Dari kesemua layanan BK tersebut, dalam penelitian ini hanya akan diambil beberapa, diantaranya: layanan orientasi, layanan informasi, layanan penempatan dan penyaluran, layanan bimbingan belajar, layanan konseling perorangan, serta layanan bimbingan dan konseling kelompok. Sedangkan untuk kegiatan penunjang yang berupa instrumen BK, himpunan data, konferensi kasus, kunjungan rumah dan alih tangan dapat dikatakan hanya sebagai alat dan kelengkapan yang harus dimiliki oleh seorang konselor atau dalam ruang lingkup sekolah disebut guru BK untuk menjalankan tugas-tugas pelayanannya.

Kaitannya dengan proses belajar, tidak sedikit siswa yang mengalami kesulitan belajar, baik itu belajar mengenal lingkungan, belajar bersosialisasi, maupun belajar dalam penyaluran bakat. Meskipun demikian, kebanyakan siswa memang mengalami kesulitan belajar dalam proses pendidikan yang berkaitan dengan mata pelajaran.

Ditilik dari usia siswa Kelas XI Administrasi Perkantoran 1 yang notabenenya adalah siswa baru mereka masih membutuhkan proses belajar mengenal lingkungan,belajar bersosialisasi dengan teman seangkatan maupun dengan kakak kelas mereka. Dapat dikatakan mereka berada pada usia yang masih rentan dan labil, dan belum mempunyai pedoman hidup yang kokoh sehingga dapat mempengaruhi proses belajarnya. Padahal belajar adalah key term atau "istilah kunci" yang paling fital dalam setiap usaha pendidikan sehingga tanpa belajar sesungguhnya tak pernah ada pendidikan. Karena demikian pentingnya arti belajar, maka bagian terbesar upaya riset dan eksperimen psikologi belajarpun diarahkn pada tercapainya pemahaman yang lebih luas dan mendalam mengenai proses perubahan manusia. Sebab perubahan dan kemampuan untuk berubah merupakan batasan dan makna yang terkandung dalam belajar . Belajar dapat didefinisikan "suatu usaha atau kegiatan yang bertujuan mengadakan perubahan di dalam diri seseorang, mencakup perubahan tingkah laku, sikap, kebiasaan, ilmu pengetahuan, keterampilan dan sebagainya".

Sedangkan di dalam psikologi belajar, proses belajar dapat berarti cara-cara atau langkah-langkah khusus yang dengan hal tersebut beberapa perubahan ditimbulkan hingga tercapai hal-hal tertentu. Jadi, proses belajar dapat diartikan sebagai tahapan perubahan perilaku kognitif, afektif dan psikomotor yang terjadi dalam diri siswa. Perubahan tersebut bersifat positif dalam arti berorientasi ke arah yang lebih maju daripada keadaan sebelumnya. 
Belajar merupakan salah satu kegiatan yang sangat penting dan harus dilakukan selama hidup, karena dengan belajar maka warga masyarakat termasuk siswa yang masih sekolah pun dapat melakukan suatu perbaikan dalam berbagai hal demi kepentingan dan kelangsungan hidupnya ataupun demi cita-cita yang telah menjadi impiannya semenjak kecil. Perwujudan perilaku belajar biasanya lebih sering tampak dalam perubahan-perubahan sebagai berikut: kebiasaan, keterampilan, pengamatan, berfikir asosiatif, dan daya ingat, berfikir rasional, sikap dan apresiasi (Slameto, 1995).

Tugas utama yang dilakukan oleh seorang siswa adalah belajar demi mencapai apa yang dicita-citakan dengan kerja keras dan kesungguhan. Namun pada kenyataannya tidak sedikit siswa yang mengalami kesulitan belajar. Kesulitan belajar tersebut dapat disebabkan oleh faktor intern, baik dari segi fisik, seperti kesehatan dan cacat badan atau dari segi psikis, seperti IQ, minat, bakat atau motivasi untuk belajar dan faktor ekstern yang datang bisa dari lingkungan keluarga, sekolah atau masyarakat.

Dengan adanya layanan BK diharapkan bisa memberi solusi terhadap kesulitan belajar yang dihadapi oleh siswa atau anak didik khususnya bagi siswa Kelas XI Administrasi Perkantoran 1 yang tidak lulus dari SMP ataupun MTS yang notabenenya siswa tersebut mempunyai problem dalam belajar sehingga mengakibatkan mereka tidak lulus yang pada akhirnya nanti bisa berprestasi baik dalam kelas maupun saat mereka lulus. Dari sinilah maka, penelitian ini akan membahas efektivitas layanan BK terhadap problem belajar siswa di SMKN 1 Tanah Grogot. Dari latar belakang masalah tersebut, maka peneliti merasa terdorong untuk mengambil judul " Implementasi Layanan Bimbingan Dan Konseling Terhadap Problem Belajar Siswa Kelas XI Administrasi Perkantoran 1 Tahun Pelajaran 2017-2018”.

\section{METODE PENELITIAN}

Penelitian ini merupakan penelitian tindakan (Action Research), karena penelitian dilakukan untuk memecahkan masalah pembelajaran di kelas. Penelitian ini juga termasuk penelitian deskriptif, sebab menggambarkan bagaimana suatu teknik pembelajaran diterapkan dan bagaimana hasil yang diinginkan dapat dicapai. Dalam penelitian tindakan ini menggunakan bentuk guru sebagai peneliti, penanggung jawab penuh penelitian ini adalah guru. Tujuan utama dari penelitian tindakan ini adalah untuk meningkatkan hasil pembelajaran di kelas dimana guru secara penuh terlibat dalam penelitian mulai dari perencanaan, tindakan, pengamatan, dan refleksi.

Penelitian tindakan telah mulai berkembang sejak perang dunia kedua. Oleh sebab itu, terdapat banyak pengertian tentang PTK. Tempat penelitian adalah tempat yang digunakan dalam melakukan penelitian untuk memperoleh data yang diinginkan. Penelitian ini bertempat di SMKN 1 Tanah Grogot tahun pelajaran 2017-2018. Waktu penelitian adalah waktu berlangsungnya penelitian atau saat penelitian ini dilangsungkan. Penelitian ini dilaksanakan pada bulan September s/d Nopember semester ganjil 2017-2018

\section{HASIL DAN PEMBAHASAN \\ Hasil \\ Siklus I}

Pada tahap ini peneliti mempersiapkan pembelajaran yang terdiri dari rencana pelajaran 1 , soal tes 1 dan alat-alat pengajaran yang mendukung. Selain itu juga dipersiapkan lembar observasi dan aktivitas siswa. Adapun proses belajar mengajar mengacu pada rencana pelajaran yang telah dipersiapkan. Pengamatan (observasi) dilaksanakan bersamaan dengan pelaksanaan belajar mengajar.Pada akhir proses belajar mengajar siswa diberi tes I dengan tujuan untuk mengetahui keberhasln siswa dalam proses layanan konseling yang telah dilakukan. Adapun data hasil penelitian pada siklus I adalah sebagai berikut: 
VOCATIONAL : Jurnal Inovasi Pendidikan Kejuruan

Vol. 1 No. 4 Oktober 2021 e-ISSN : 2774-6283 | p-ISSN : 2775-0019

Tabel 1. Hasil Tes Siklus I

\begin{tabular}{|c|c|c|c|c|c|c|c|c|c|}
\hline \multirow{3}{*}{ No } & \multirow{3}{*}{ Nama } & \multirow{2}{*}{\multicolumn{4}{|c|}{$\begin{array}{c}\text { Aspek yang } \\
\text { dinilai }\end{array}$}} & \multirow{3}{*}{$\begin{array}{c}\text { Jumlah } \\
\text { Skor }\end{array}$} & \multirow{3}{*}{ Nilai } & \multirow{3}{*}{ Tuntas } & \multirow{3}{*}{$\begin{array}{c}\text { Tdk } \\
\text { Tuntas }\end{array}$} \\
\hline & & & & & & & & & \\
\hline & & $\mathrm{A}$ & $\mathrm{B}$ & $\mathrm{C}$ & $\mathrm{D}$ & & & & \\
\hline 1. & Agus Miwati & 2 & 2 & 2 & 3 & 9 & 75 & $\sqrt{ }$ & \\
\hline 2. & Anden Setya Renggani & 2 & 3 & 3 & 2 & 10 & 83 & $\sqrt{ }$ & \\
\hline 3. & Azkiyatul Mukhibah & 2 & 3 & 2 & 2 & 9 & 75 & $\sqrt{ }$ & \\
\hline 4. & Boy Mansyah & 2 & 3 & 3 & 2 & 10 & 83 & $\sqrt{ }$ & \\
\hline 5. & Dea Permatasari & 1 & 2 & 3 & 3 & 9 & 75 & & $\sqrt{ }$ \\
\hline 6. & Dhea Sandrina Noor & 3 & 2 & 2 & 2 & 9 & 75 & $\sqrt{ }$ & \\
\hline 7. & Dina & 3 & 2 & 2 & 3 & 10 & 83 & $\sqrt{ }$ & \\
\hline 8. & Ema Indriani & 2 & 2 & 3 & 1 & 8 & 67 & & $\sqrt{ }$ \\
\hline 9. & Ema Kartika & 1 & 1 & 2 & 1 & 5 & 42 & & $\sqrt{ }$ \\
\hline 10. & Eny Januarisni Rahmah & 2 & 2 & 3 & 1 & 8 & 67 & & $\sqrt{ }$ \\
\hline 11. & Hairil Hasrin & 2 & 1 & 2 & 1 & 6 & 50 & & $\sqrt{ }$ \\
\hline 12. & Hajar Nuri & 2 & 2 & 2 & 3 & 9 & 75 & $\sqrt{ }$ & \\
\hline 13. & Heru Kusnanto & 2 & 2 & 2 & 3 & 9 & 75 & & $\sqrt{ }$ \\
\hline 14. & Iga Fauziah & 2 & 1 & 3 & 2 & 8 & 67 & & $\sqrt{ }$ \\
\hline 15. & Jihan Fitriyah & 1 & 1 & 2 & 2 & 6 & 50 & & $\sqrt{ }$ \\
\hline 16. & Joel Permana Alam & 3 & 2 & 2 & 3 & 10 & 83 & $\sqrt{ }$ & \\
\hline 17. & Mariatul Kiptiah & 2 & 2 & 3 & 1 & 8 & 67 & & $\sqrt{ }$ \\
\hline 18. & Mariyanti & 3 & 2 & 3 & 2 & 10 & 83 & $\sqrt{ }$ & \\
\hline 19. & Mirda & 2 & 3 & 2 & 3 & 10 & 83 & $\sqrt{ }$ & \\
\hline 20. & Muhammad Yusuf Akbar & 2 & 2 & 2 & 3 & 9 & 75 & $\sqrt{ }$ & \\
\hline 21. & Nadya Amaliah & 2 & 2 & 2 & 3 & 9 & 75 & $\sqrt{ }$ & \\
\hline 22. & Niken Wulan Ochtiasari & 2 & 2 & 2 & 3 & 9 & 75 & $\sqrt{ }$ & \\
\hline 23. & Nike Putri Sari Dila & 2 & 2 & 2 & 3 & 9 & 75 & $\sqrt{ }$ & \\
\hline 24. & Nor Isdayanti & 2 & 2 & 2 & 3 & 9 & 75 & $\sqrt{ }$ & \\
\hline 25. & Nur Halimah & 1 & 1 & 2 & 2 & 6 & 50 & & $\sqrt{ }$ \\
\hline 26. & Ori Andriani Saputri & 2 & 2 & 2 & 3 & 9 & 75 & $\sqrt{ }$ & \\
\hline 27. & Resti Pebriyanti & 2 & 2 & 2 & 3 & 9 & 75 & $\sqrt{ }$ & \\
\hline 28. & Retna Nur Rahmahyanti & 3 & 2 & 3 & 2 & 10 & 83 & $\sqrt{ }$ & \\
\hline 29. & Silviyanti Dwi Anggraini & 3 & 2 & 3 & 2 & 10 & 83 & $\sqrt{ }$ & \\
\hline 30. & Siti Aulia Rahmah & 2 & 2 & 2 & 3 & 9 & 75 & $\sqrt{ }$ & \\
\hline 31. & Siti Masitah & 2 & 2 & 2 & 3 & 9 & 75 & $\sqrt{ }$ & \\
\hline 32. & Slamet Riyadi & 3 & 2 & 3 & 2 & 10 & 83 & $\sqrt{ }$ & \\
\hline 33. & Sri Hartati & 2 & 2 & 2 & 3 & 9 & 75 & $\sqrt{ }$ & \\
\hline 34. & Widia Safitri & 1 & 1 & 2 & 2 & 6 & 50 & & $\sqrt{ }$ \\
\hline 35. & Yeni Ulandari & 2 & 2 & 3 & 1 & 8 & 67 & & $\sqrt{ }$ \\
\hline & & & & & & & 2524 & 23 & 12 \\
\hline $\begin{array}{l}\text { Jum } \\
\text { Jum } \\
\text { Rata } \\
\text { Pros }\end{array}$ & $\begin{array}{l}\text { ah seharusnya }=3500 \\
\text { ah yang diperoleh }=2524 \\
\text { rata }=72 \\
\text { entase }=65 \%\end{array}$ & & & & & & & & \\
\hline
\end{tabular}

Keterangan :

A. Belajar Terencana Dan Teratur

B. Disiplin Dalam Belajar

C. Memiliki Tujuan Dalam Belajar

D. Memiliki Kepercayaan Terhadap Kemampuan Sendiri 
Dari tabel di atas jelas terlihat bahwa siswa yang nilai skor diatas minimal (72) adalah sebesar 65\%. Dalam tabel tersebut masih banyak yang sebesar 35\% belum tuntas sehingga perlu adanya kegiatan selanjutnya yaitu melakukan siklus II. Banyak faktor yang terjadi akibat banyaknya yang tidak lulus. Dari hasil refleksi di dapatkan siswa kurang bisa antusias selama layanan.

\section{Siklus II}

Pada tahap ini peneliti mempersiapkan pembelajaran yang terdiri dari rencana layanan konseling 2, soal tes 2 dan alat-alat pengajaran yang mendukung. Selain itu juga dipersiapkan lembar observasi dan aktivitas siswa. Pengamatan (observasi) dilaksanakan bersamaan dengan pelaksanaan belajar mengajar. Sebagai pengamat adalah peneliti dibantu oleh seorang guru Bimbingan dan Konseling.

Pada akhir proses belajar mengajar siswa diberi tes Psikomotor II dengan tujuan untuk mengetahui tingkat keberhasilan siswa dalam proses belajar mengajar yang dilakukan. Instrument yang digunakan adalah tes praktek II. Adapun data hasil penelitian pada siklus II adalah sebagai berikut:

Tabel 2. Hasil Tes Siklus II

\begin{tabular}{|c|c|c|c|c|c|c|c|c|c|}
\hline \multirow[t]{2}{*}{ No } & \multirow[t]{2}{*}{ Nama } & \multicolumn{4}{|c|}{$\begin{array}{c}\text { Aspek yang } \\
\text { dinilai }\end{array}$} & \multirow[t]{2}{*}{$\begin{array}{c}\text { Jumlah } \\
\text { Skor }\end{array}$} & \multirow[t]{2}{*}{ Nilai } & \multirow[t]{2}{*}{ Tuntas } & \multirow[t]{2}{*}{$\begin{array}{l}\text { Tdk } \\
\text { Tuntas }\end{array}$} \\
\hline & & A & $\mathrm{B}$ & $\mathrm{C}$ & $\mathrm{D}$ & & & & \\
\hline 1. & Agus Miwati & 2 & 2 & 2 & 3 & 9 & 75 & $\sqrt{ }$ & \\
\hline 2. & Anden Setya Renggani & 2 & 3 & 3 & 2 & 10 & 83 & $\sqrt{ }$ & \\
\hline 3. & Azkiyatul Mukhibah & 2 & 3 & 2 & 2 & 9 & 75 & $\sqrt{ }$ & \\
\hline 4. & Boy Mansyah & 2 & 3 & 3 & 2 & 10 & 83 & $\sqrt{ }$ & \\
\hline 5. & Dea Permatasari & 2 & 2 & 2 & 3 & 9 & 75 & $\sqrt{ }$ & \\
\hline 6. & Dhea Sandrina Noor & 3 & 2 & 2 & 2 & 9 & 75 & $\sqrt{ }$ & \\
\hline 7. & Dina & 3 & 2 & 2 & 3 & 10 & 83 & $\sqrt{ }$ & \\
\hline 8. & Ema Indriani & 3 & 2 & 2 & 3 & 10 & 83 & $\sqrt{ }$ & \\
\hline 9. & Ema Kartika & 3 & 2 & 2 & 3 & 10 & 83 & $\sqrt{ }$ & \\
\hline 10. & Eny Januarisni Rahmah & 3 & 2 & 2 & 2 & 9 & 75 & $\sqrt{ }$ & \\
\hline 11. & Hairil Hasrin & 2 & 2 & 3 & 1 & 8 & 67 & & $\sqrt{ }$ \\
\hline 12. & Hajar Nuri & 3 & 3 & 3 & 3 & 12 & 100 & $\sqrt{ }$ & \\
\hline 13. & Heru Kusnanto & 2 & 2 & 2 & 3 & 9 & 75 & $\sqrt{ }$ & \\
\hline 14. & Iga Fauziah & 2 & 1 & 3 & 2 & 8 & 67 & & $\sqrt{ }$ \\
\hline 15. & Jihan Fitriyah & 3 & 2 & 2 & 3 & 10 & 83 & $\sqrt{ }$ & \\
\hline 16. & Joel Permana Alam & 3 & 3 & 2 & 3 & 11 & 92 & $\sqrt{ }$ & \\
\hline 17. & Mariatul Kiptiah & 2 & 2 & 3 & 1 & 8 & 67 & & $\sqrt{ }$ \\
\hline 18. & Mariyanti & 3 & 3 & 2 & 3 & 11 & 92 & $\sqrt{ }$ & \\
\hline 19. & Mirda & 3 & 3 & 3 & 3 & 12 & 100 & $\sqrt{ }$ & \\
\hline 20. & Muhammad Yusuf Akbar & 2 & 2 & 2 & 3 & 9 & 75 & $\sqrt{ }$ & \\
\hline 21. & Nadya Amaliah & 2 & 2 & 2 & 3 & 9 & 75 & $\sqrt{ }$ & \\
\hline 22. & Niken Wulan Ochtiasari & 3 & 3 & 2 & 3 & 11 & 92 & $\sqrt{ }$ & \\
\hline 23. & Nike Putri Sari Dila & 2 & 2 & 2 & 3 & 9 & 75 & $\sqrt{ }$ & \\
\hline 24. & Nor Isdayanti & 3 & 3 & 2 & 3 & 11 & 92 & $\sqrt{ }$ & \\
\hline 25. & Nur Halimah & 2 & 2 & 2 & 3 & 9 & 75 & $\sqrt{ }$ & \\
\hline 26. & Ori Andriani Saputri & 2 & 2 & 2 & 3 & 9 & 75 & $\sqrt{ }$ & \\
\hline 27. & Resti Pebriyanti & 2 & 2 & 2 & 3 & 9 & 75 & $\sqrt{ }$ & \\
\hline 28. & Retna Nur Rahmahyanti & 3 & 2 & 3 & 2 & 10 & 83 & $\sqrt{ }$ & \\
\hline 29. & Silviyanti Dwi Anggraini & 3 & 2 & 3 & 2 & 10 & 83 & $\sqrt{ }$ & \\
\hline 30. & Siti Aulia Rahmah & 2 & 2 & 2 & 3 & 9 & 75 & $\sqrt{1}$ & \\
\hline 31. & Siti Masitah & 2 & 2 & 2 & 3 & 9 & 75 & $\sqrt{ }$ & \\
\hline
\end{tabular}


Vol. 1 No. 4 Oktober 2021 e-ISSN : 2774-6283 | p-ISSN : 2775-0019

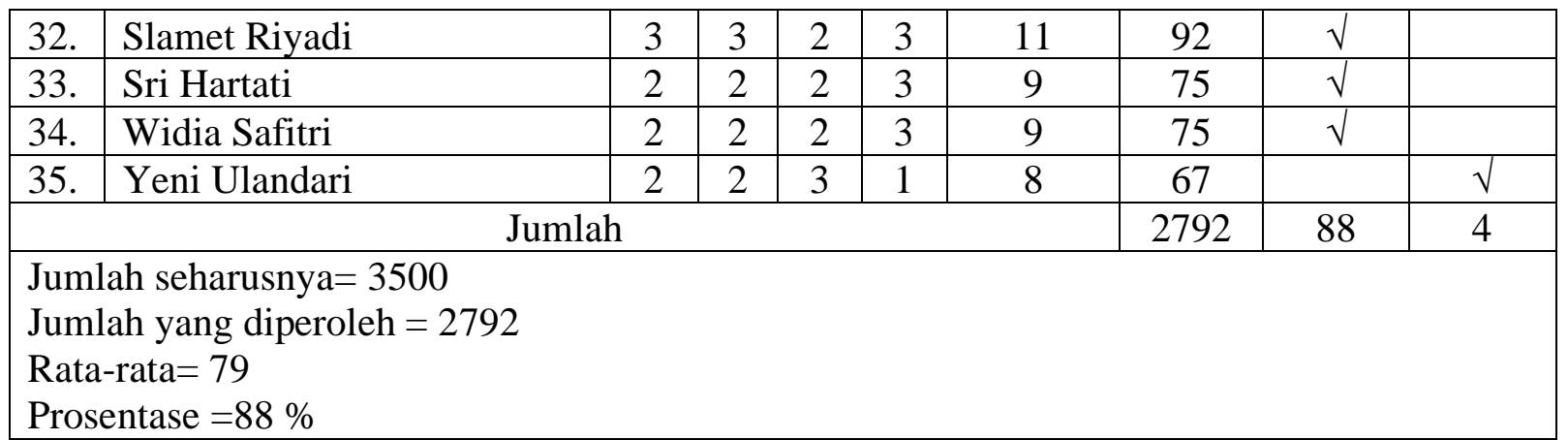

Keterangan :

A. Belajar Terencana Dan Teratur

B. Disiplin Dalam Belajar

C. Memiliki Tujuan Dalam Belajar

D. Memiliki Kepercayaan Terhadap Kemampuan Sendiri

Dari tabel di atas jelas terlihat bahwa siswa yang nilai skor diatas minimal (79) adalah sebesar $88 \%$. Hal ini berarti siklus 2 sudah mencapai maksimal yaitu diatas 85\%. Dari pelaksanaan siklus II terdapat beberapa refleksi diantaranya Siswa mulai antusias selama layanan konseling. Pelaksanaan kegiatan bimbingan konseling pada siklus II ini sudah berjalan dengan baik dan mendapatkan perubahan yang signifikan dalam kedisiplinan guru di dalam kelas berupa pelaksanaan layanan konseling.

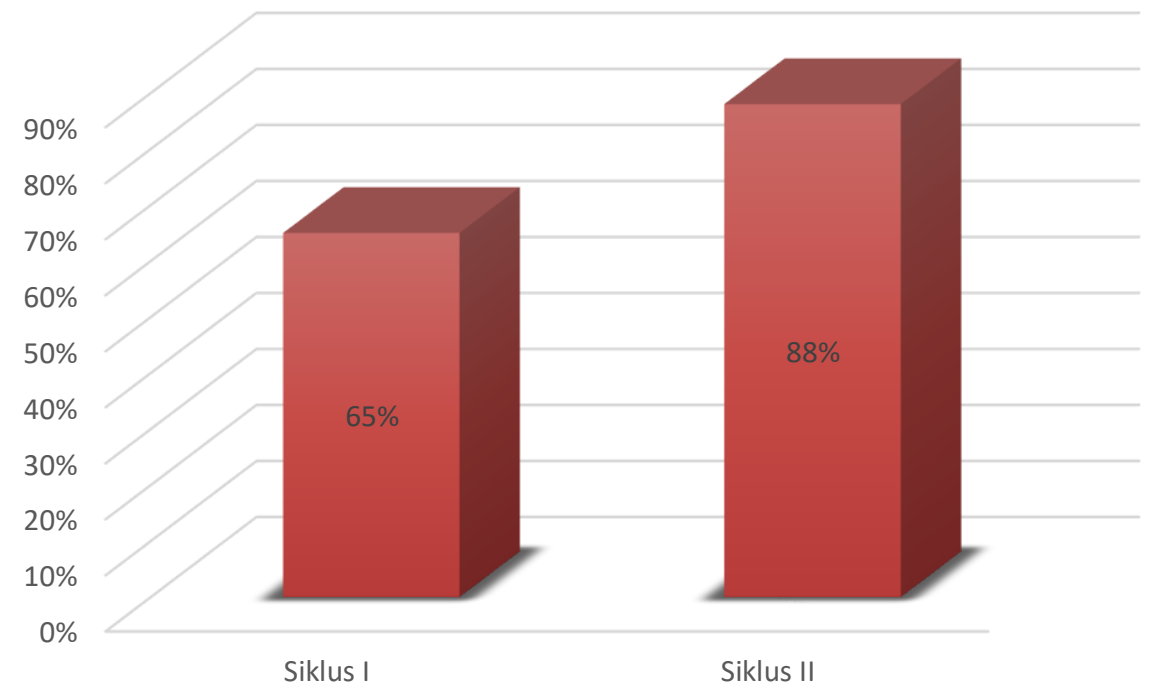

Gambar 1. Perbandingan Hasil Siklus I dan Siklus II

\section{Pembahasan}

\section{Ketercapaian Hasil belajar siswa}

Melalui hasil penelitian ini menunjukkan bahwa pemberian layanan dengan methode reinforcement memiliki dampak positif dalam meningkatkan motivasi belajar siswa. Hal ini dapat dilihat dari semakin mantapnya pemahaman siswa terhadap materi yang disampaikan guru (Ketercapaian belajar meningkat dari siklus I, II dan III) untuk ranah psikomotor yaitu siklus I (72\%), siklus II (88\%) pada siklus II Ketercapaian nilai siswa secara klasikal.

\section{Kemampuan Guru dalam Mengelola Pembelajaran}

Berdasarkan analisis data, diperoleh aktivitas siswa dalam proses belajar mengajar dengan menerapkan metode reinforcement dalam setiap siklus mengalami peningkatan. Hal ini 
berdampak positif terhadap prestasi belajar siswa yaitu dapat ditunjukkan dengan meningkatnya nilai rata — rata siswa pada setiap siklus yang terus mengalami peningkatan.

\section{Aktivitas Siswa dalam Pembelajaran}

Berdasarkan analisis data, diperoleh aktivitas siswa dalam proses pembelajaran dengan model pembelajaran paling dominan adalah belajar dengan sesama anggota kelompok, mendengarkan/memperhatikan penjelasan guru dan diskusi antara siswa/antara siswa dengan guru. Jadi dapat dikatakan bahwa aktivitas siswa dapat dikategorikan aktif. Sedangkan untuk aktivitas guru selama pembelajaran telah melaksanakan langkah-langkah metode reinforcement dengan baik. Hal ini terlihat dari aktivitas guru yang muncul di antaranya aktivitas membimbing dan mengamati siswa dalam mempraktikkan hasil pembelajaran, menjelaskan/melatih menggunakan alat, memberi umpan balik dalam prosentase untuk aktivitas di atas cukup besar.

\section{KESIMPULAN}

Dari hasil kegiatan pembelajaran yang telah dilakukan selama tiga siklus dan berdasarkan seluruh pembahaan serta analisis yang telah dilakukan dapa disimpulkan sebagai berikut

1. Layanan Bimbingan Konseling dengan metode ini memiliki dampak positif dalam meningkatkan motivasi belajar siswa yang ditandai dengan peningkatan Ketercapaian nilai siswa dalam setiap siklus, yaitu siklus I (72\%), dan siklus II (88\%)

2. Penerapan metode layanan bimbingan konseling ini mempunyai pengaruh positif, yaitu dapat meningkatkan motivasi belajar siswa yang ditunjukkan dengan rata-rata jawaban siswa yang menyatakan bahwa siswa tertarik dan berminat dengan metode pembelajaran ini sehingga mereka menjati termotivasi untuk belajar.

\section{DAFTAR PUSTAKA}

Corey, G. (2005). Teori dan praktek konseling dan psikoterapi, (Terj. E. Koswara). Bandung: Refika Aditama.

Depdikas. (2008). Penataan pendidikan profesional konselor dan konseling dalam jalur formal. Jakarta: Depdiknas.

Gysbers, N. C. (2001). School guidance and counseling in the 21st century: Remember thepast into the future. Professional School Counseling, 5(2), 96-106.

Habsy, B. A. (2017b). Semar puppet counseling model. COUNS-EDU: The International Journal of Counseling and Education, 2(1), 19-24.

Habsy, B. A., Hidayah, N., \& Lasan, B. B. (2017). A literature review of indonesian life concept linuwih based on the teachings of adiluhung Raden Mas Panji Sosrokartono. Advances in Social Science, Education and Humanities Research, 128, 64-73.

Hallen A. (2002). Bimbingan dan Konseling. Jakarta : Ciputat Pers.

Slameto. (1995). Belajar dan Faktor-faktor Yang Mempengaruhinya. Jakarta : PT. Rineka Cipta.

Suharsimi, Arikunto. (1984). Dasar-Dasar Evaluasi Pendidikan. Jakarta : PT. Rineka Cipta. Sukardi, Dewa Ketut. (1985). Pengantar Teori Konseling. Jakarta : Ghalia Indonesia. 